\section{GAME OF THRONES -PELIN LET'S PLAY -VIDEOT JA POPULAARIKULTTUURIN VASTAANOTTO ESITYKSENÄ}

Artikkeli tarkastelee suosittuun Valtaistuinpeli-tv-sarjaan perustuvan pelin Let's Play -videoita fanikulttuurisina käytäntöinä ja osana Valtaistuinpelin transmediaalista universumia. Pelaaja-kertojien kautta analysoidaan tapoja, joilla ihmiset kokevat maailman, hahmot ja tapahtumat, ja sitä, miten he niitä tulkitsevat ja suhteuttavat omaan elämänkokemukseensa. Let's Play-videot tarjoavat hedelmällisen aineiston pelien ja yleisemmin populaarikulttuurin synnyttämien kokemusten tarkasteluun.

Game of Thrones, suomeksi Valtaistuinpeli, on George R. R. Martinin fantasiakirjasarjaan The Song of Ice and Fire ${ }^{1}$ perustuva, erittäin suosittu televisiosarja (viimeinen, 8. kausi nähtiin keväällä 2019). Sarja on voittanut lukuisia palkintoja, rikkonut erilaisia ennätyksiä ja tämän lisäksi ollut myös kriitikoiden korkealle arvostama. Sarjan viimeinen kausi tosin sai edeltäjiään huomattavasti kriittisemmän vastaanoton. Sarja on kiinnittänyt huomiota sekä rohkeilla ja kyseenalaisilla seksikohtauksilla (sisältävät raiskauksia ja insestiä) että raa'alla väkivallallaan. Erityisesti tarina tunnetaan siitä, että kukaan henkilöistä ei ole turvassa. Usea keskeisessä roolissa ollut hahmo on saanut yllättävän ja väkivaltaisen lopun televisiosarjojen konventioita rikkovalla tavalla. Tulen ja jään laululla ja Valtaistuinpelillä on laaja ja aktiivinen fanikunta, joka ottaa voimakkaasti kantaa sarjan tapahtumiin, luo ja kierrättää sarjaan perustuvia meemejä ja tuottaa mm. Valtaistuinpeli-aiheisia videoita.

Valtaistuinpelin sekä Tulen ja jään laulun ympärille on kasvanut rikas ja monipuolinen transmediauniversumi. ${ }^{2}$ Siihen sisältyy romaanien ja televisiosarjan lisäksi mm. digitaalisia pelejä, lautapelejä, Thronecast-sisältöä ja musiikkialbumeita, sekä loputon määrä fanitaidetta ja muuta fanien tuottamaa sisältöä. Televisiosarjan kuusi ensimmäistä kautta perustuivat hyvin tarkasti kirjasarjan tarinaan, mutta seitsemäs ja kahdeksas kausi lähtevät omille poluilleen, sillä kirjasarja ei ole vielä edistynyt yhtä pitkälle (Martin on tunnettu hitaasta kirjoittamistahdistaan). Transmediaalisen tarinankerronnan yksi kulmakivistä on ajatus siitä, että kokonaisuudessa jokainen mediamuoto tekee asioita, jotka
1 Ensimmäiset viisi kirjaa julkaistu 1996; 1998; 2000; 2005; 2011; suomeksi Tulen ja jään laulu, 2003; 2004; kolmas kirja kahtena niteenä 2005 ja 2006; 2007; viides kirja kahtena niteenä, kummatkin 2014.

2 Transmediauniversumin käsite sisältää narratiivisia ja ei-narratiivisia elementtejä, diegeettisiä ja ekstradiegeettisiä elementtejä sekä virallisia tuotantoja ja fanien tuottaman sisällön (Anon., arvioitavana). Esimerkiksi tv-sarjan näyttelijät ovat julkkiksia, jotka esiintyvät niin mediassa kuin meemeissä, ja nämä esiintymiset on perusteltua sisällyttää myös transmediauniversumiin. 
juuri kyseiseen parhaiten soveltuvat. Eri medioiden välillä ei myöskään pitäisi olla vahvaa hierarkiaa, vaan jokaisella medialla on tasa-arvoinen paikkansa kokonaisuudessa. Käytännössä transmediaaliset kokonaisuudet kuitenkin pääsääntöisesti rakentuvat yhden mediasisällön ympärille ja tämä ydinteksti (core text) on esimerkiksi Jason Mittellin (2015, 294-295) tutkimissa tapauksissa tv-sarja. Myös elokuvien ympärille on rakentunut merkittäviä transmediauniversumeja (Star Wars, Marvel Cinematic Universe). Valtaistuinpelin kohdalla ydintekstiksi olisi ilmeistä nimetä Tulen ja jään laulu -kirjasarja, mutta tv-sarjan onnistunut toteutus ja suuri suosio ovat nostaneet sen kirjasarjan ohella ydintekstin asemaan; ja useiden fanien mielestä ehkä syrjäyttänytkin sen.

Erityisesti tv-sarjan myötä Valtaistuinpelin transmediauniversumista on tullut ilmiö, jolla on faneja huomattavasti laajemmin kuin vain fantasiaharrastajien piirissä. Game of Thrones Project -tutkimushankkeen ${ }^{3}$ kaltaisilla kyselyillä pystytään selvittämään joitain niistä syistä, miksi ihmiset pitävät juuri tästä tarinamaailmasta. Tässä artikkelissa pyrin pääsemään kiinni tapoihin, joilla ihmiset kokevat Valtaistuinpelin maailman, hahmot ja tapahtumat, ja miten he tulkitsevat niitä ja suhteuttavat omaan elämänkokemukseensa. Hypoteesina on, että Let's Play -videot tarjoavat hedelmällisen aineiston pelien ja yleisemmin populaarikulttuurin synnyttämien kokemusten tarkasteluun. Tutkimusmenetelmänäni onkin Game of Thrones -videopelistä tehtyjen ja verkossa julkaistujen Let's Play -videoiden ja niihin liittyvän kommentoinnin analysointi erityisesti videon julkaisseen pelaajan esiintymiseen keskittyen. Varsinaiset tutkimuskysymykseni ovat: millä tavoin Let's Play -videot asettuvat osaksi fanikulttuurisia käytäntöjä ja mitä Valtaistuinpelin transmediaalisen universumin piirteitä videoiden tekijät erityisesti nostavat esille.

Esittelen jatkossa ensin Telltale-yhtiön tekemän Game of Thrones -pelin ja kuvaan sitten Let's Play -videoiden keskeisiä piirteitä. Tämän jälkeen kuvaan tarkemmin aineistoni ja esittelen tärkeimmät havainnot keskittyen erityisesti siihen, miten Let's Play -videoiden tekijät esittävät Valtaistuinpeli-faniutensa, sekä miten moraaliset pelivalinnat nousevat Game of Thrones -pelin kohdalla esityksen keskiöön.

\section{Game of Thrones -peli}

Telltale Games tunnetaan televisiosarjojen pohjalta tehdyistä, episodeittain julkaistuista peleistään. Game of Thrones -pelin ohella sen Walking Dead -pelit ovat olleet suosittuja. Näissä tarinavetoisissa peleissä pelaajan keskeinen tehtävä on valita eri vastausvaihtoehdoista (tai muista reagointimahdollisuuksista), kun hänen pelihahmonsa on tekemisissä muiden hahmojen kanssa. Lisäksi peleissä on satunnaisesti toimintajaksoja, joissa on kyse yleensä taistelemisesta, ja joissa pelaajan haasteena on ajoittaa toimensa (esim. kosketusnäytölle ilmestyvän merkin hipaisu) oikein. Telltale on luonut vahvan mielikuvan siitä, kuinka pelaajan valinnat vaikuttavat tarinaan ja tuottavat erilaisia loppuratkaisuja. Käytännössä erilaisia tarinavariantteja on kuitenkin melko vähän, eikä monilla valinnoilla tosiasiallisesti ole mitään merkitystä loppuratkaisun kannalta. Kuitenkin jo se vaikutelma, että valinnat ovat merkityksellisiä, on tärkeää pelikokemukselle. Yksittäisellä pelaajalla ei myöskään ole yleensä vertailukohtaa (ellei hän pelaa samaa peliä useaan kertaan), joten hän ei pysty kovinkaan kattavasti tarkastelemaan millä muilla tavoilla tarina voisi päättyä. Telltalen peleissä jokaisessa yksittäisessä episodissa on rajallinen määrä tarinan kannalta keskeisiä valintoja (Game of Thrones -pelissä viisi
$3<$ https://jyx.jyu.fi/handle/123456789/66430>. Linkki tarkistettu 21.11.2019. 
valintakohtaa kussakin episodissa), joiden osalta pelaajan ratkaisut tallennetaan pelin verkkopalvelimille, ja pelattuaan episodin loppuun pelaajalle näytetään valintojen jakautuminen kaikkien pelaajien keskuudessa. Tämä ei suoraan kerro valintojen vaikutuksesta tarinaan, mutta antaa pelaajalle kokonaiskuvan kuinka tyypillisiä tai epätyypillisiä hänen omat valintansa ovat olleet.

Game of Thrones -peli julkaistiin kuudessa osassa joulukuusta 2014 marraskuuhun 2015. Se julkaistiin kaikille keskeisille alustoille, sekä mobiililaitteille (iOS, Android), konsoleille (PS3, PS4, Xbox 360, Xbox One) että PC:lle (Windows, OS X). Pelin pystyi ostamaan joko episodi kerrallaan, maksamalla tilausmaksun, jolla sai kaikki episodit sitä mukaa kun ne julkaistiin, tai viimeisen episodin jälkeen ostamalla koko sarja yhtenä pakettina. Peli sai kohtalaisen positiivisen vastaanoton, ja Metacritic-sivuston yhteenvedossa pisteytetyt arviot olivat pääosin 70-80 pistettä sadasta (arviot jokaisen episodin eri alustaversioille erikseen). Saman yhtiön aiempi, myöskin tv-sarjaan liittyvä Walking Dead -peli (2012) keräsi jonkin verran paremmat arviot (80-90 pistettä), samoin Borderlands-ammuntaroolipelisarjan (Gearbox Software 2009; "role-playing shooter") pohjalta tehty Tales from the Borderlands (2014-2015; 78-90 pistettä). Game of Thrones -peli siis jäi hieman näiden suosiosta, mutta Telltale suunnitteli sille silti jatko-osan. Yhtiö kuitenkin lopetti itsenäisen pelituotannon syksyllä 2018 ja samalla jatko-osa haudattiin. Spekulaatioita Telltalen pelituotannon jatkamisesta mahdollisesti uuden yhtiön nimissä on esiintynyt, ja nyt kun Valtaistuinpeli-transmediamaailmaan sijoittuva uusi tv-sarja, House of the Dragon, on työn alla, on täysin mahdollista, että Game of Thrones -pelikin tulee vielä saamaan jatkoa.

Pelin tapahtumat liittyvät melko tiiviisti kirjojen ja televisiosarjan tarinaan, mutta siten, että pelin hahmot ja tapahtumapaikat eivät pääosin esiinny niissä. Pelin tapahtumat sijoittuvat tv-sarjan neljännen kauden kanssa samoihin aikoihin ja Carlos Scolarin $(2009,598)$ transmediaalisen kerronnan eri muotojen jaottelussa Game of Thrones -pelin toteutustapa sijoittuu selkeästi rinnakkaisen kerronnan (parallel stories) kategoriaan. Pelitapahtumien keskiössä on House Forrester, joka mainitaan kirjasarjassa ohimennen, eikä esiinny televisiosarjassa lainkaan. Mukana tapahtumissa on muutama tuttu, keskeinen hahmo (kuningatar Margaery, Ramsay Bolton), mutta he eivät ole pelattavia hahmoja. Valtaistuinpelin tapaisessa fiktiivisessä maailmassa, jossa on hyvin paljon seurattavia henkilöitä ja kerronta etenee useiden näkökulmahenkilöiden välityksellä, tämä on toimiva ratkaisu ja onnistuu luomaan samaan aikaan tuntuman siitä, että pelaajana ollaan mukana tutussa maailmassa. Toisaalta tilaa jää myös uusille juonikuvioille, joiden ei tarvitse seurata jo aiemmin koettuja käänteitä.

Visuaalisesti peli noudattelee hyvin tarkasti televisiosarjan esikuvaa. Sarjasta tutut hahmot näyttävät samoilta kuin sarjassa, mutta yleisemminkin pelin visuaalinen ilme on lainattu suoraan televisiosarjasta, samoin jokaisen peliepisodin alussa nähtävä intro tunnusmusiikkeineen. Tässä suhteessa Game of Thrones -peli tukee ajatusta nimenomaan tv-sarjasta Valtaistuinpelin ydintekstinä. Peli itsessään on selvästi rajatumpi kokonaisuus kuin Tulen ja jään laulu tai Valtaistuinpeli. Se kattaa vain lyhyehkön ajanjakson ja rajallisen joukon henkilöitä, ja tässä suhteessa pelin voi katsoa täydentävän ydintekstien tarinamaailmaa sekä esittelemällä joitain uusia hahmoja että tuomalla uusia yksityiskohtia ydinteksteistä tuttuihin hahmoihin ja itse tarinamaailmaan.

Game of Thrones -pelissä on hyvin tunnistettavissa Martinin luoman tarinan raa'an väkivallan eetos. Pelin aikana kuolee suuri joukko ihmisiä, pääasiassa 
hyvin verisillä tavoilla. Toisaalta peli poikkeaa esikuvistaan huomattavasti sikäli, että siinä ei ole lainkaan mukana seksiä eikä alastomuutta. Pelaaja kohtaa äärimmäisiä tilanteita, joissa hän joutuu tekemään valintoja elämän ja kuoleman välillä, aivan kuten Martinin luomat hahmotkin. Tilanne on kuitenkin pelissä erilainen kuin televisiosarjan kohdalla, kun pelaaja itse tekee päätöksiä, eikä vain seuraa miten muut toimivat. Kokemus on parhaimmillaan erittäin intensiivinen.

\section{Let's Play -videot}

Let's Play -videot ovat (yleensä digitaalisten pelien, mutta joskus esimerkiksi lautapelien) pelaamisesta tehtyjä videoita, joita jaellaan netin videoalustoilla. Suosituin alusta on Youtube. Myös pelaamisen reaaliaikaiseen striimaamiseen keskittyvässä Twitchissä julkaistaan jonkin verran Let's Play -videoita, mutta niiden osuus siellä on marginaalinen suhteessa live-kanaviin. Let's Play -videoita voidaan jaotella erilaisiin genreihin, mutta kaikille niille on yhteistä näyttää tietyn pelin pelaamista, niin että ruudulla näkyy pelitapahtumat. Nykyiset pelikonsolit tarjoavat erittäin helppokäyttöset toiminnot joko pelin tallentamiseen tai live-striimaamiseen, joten erityisiä teknisiä taitoja videointiin ei välttämättä tarvita. Ääniraidalla pelaaja kommentoi omaa pelaamistaan ja pelitapahtumia eri tavoin. Pelaaja itse saattaa näkyä videolla pelikuvan päällä, joko niin että kuvaan on rajattu vain kasvot, tai laajempanakin otoksena. Pelaajan puheet pelaamisen aikana ovat merkittävä elementti Let's Play -videoissa. Hän voi kommentoida esimerkiksi tekemiään valintoja, kiinnittää katsojan huomion erilaisiin yksityiskohtiin ja antaa pelivinkkejä, tai hän voi kertoa omin sanoin mitä pelissä tapahtuu (tällöin hän kerronnallistaa peliä) tai kertoilla sattumuksia elämästään.

Osa videoiden tekijöistä toimii pelaaja-kertojina, jotka limittävät saumattomasti yhteen oman pelaamisensa ja pelin kerronnallistamisen. Pelaajapersoonallisuudet ovat yksi merkittävistä tekijöistä Let's Play -videoiden suosiolle ja osa heistä on noussut sosiaalisen median tähdiksi. Esimerkiksi ruotsalainen PewDiePie, jolla on yli 100 miljoonaa seuraajaa, tuli tunnetuksi nimenomaan Let's Play -videoillaan, vaikka onkin myöhemmin muuttunut enemmän yleisvloggaajaksi. Vastaavalla tavalla Suomessa suosittu Let's Play -videoiden tekijä Lakko siirtyi suuren suosion myötä tuottamaan muunkinlaisia vlogeja Let's Playn ohella. "To put it simply, an LP is a story about playing a video game, in which the main character is the player, not the original protagonist of the game." (Kerttula 2019, 253.)

Valtaosalla Let's Play -videoiden tekijöistä on YouTubessa oma kanavansa, ja kanavan tilanneet seuraajat saavat automaattisesti tiedon uuden videon julkaisusta. Kanavan tilaaminen itsessään on maksutonta, mutta seuraajat voivat maksaa vapaaehtoisia maksuja tukeakseen videoiden julkaisuja. Osalla julkaisijoista on erilaisia maksullisia jäsenyysohjelmia, joihin liittymällä saa nähdäkseen lisäsisältöä tai vaikkapa mahdollisuuden vaikuttaa tulevien videoiden aiheisiin. Katsojilta tulevien lahjoitusten ohella toinen ansaintatapa on solmia mainossopimuksia, joiden arvo määräytyy kanavan seuraajamäärän pohjalta. Monet Let's Play -videoiden tekijöistä eivät kuitenkaan saa toiminnastaan minkäänlaista rahallista korvausta, vaan kyse on itsessään mielihyvää tuottavasta harrastuksesta. Internetin loputtomassa sisältötulvassa oman videokanavan esiin tuominen on vaikeaa ja monet julkaisut jäävätkin vain lähipiiriin huomaamiksi. Lähtökohtaisesti kyse on harrastajien ja fanien 
toisille samanmielisille tekemästä sisällöstä, joka leviää tuttavaverkostoissa. Onnekas sattuma (hyvin valittu tunniste, ajoitus, jne.) tai kaupallinen yhteistyö voivat antaa sysäyksen suurempaan suosioon. Kun seuraajamäärät nousevat kymmeniin tuhansiin, harrastus voi muuttua myös ansaintakeinoksi, jolloin videoiden tekijän tulee aiempaa enemmän ottaa huomioon yleisön ja yhteistyökumppanien odotukset omassa tuotannossaan.

Osa Let's Play -videoista on niin sanotusti sokkoja (blind), jolloin pelaaja on ensimmäistä kertaa tekemisissä pelin kanssa, eikä tiedä millaisia tapahtumia siinä tulee eteen. Toisena ääripäänä ovat videot, joiden tekijä tuntee pelin läpikotaisin ja joko esittelee suvereeniuttaan pelaajana tai antaa pelin huonommin tunteville katsojille vinkkejä hyvistä pelistrategioista. Osa videoista on täysin editoimattomia, jolloin ne julkaistaan suoraan sellaisena kuin ne pelilaitteen tallentamina ovat. Toisia taas on voitu editoida runsaastikin ja leikata esimerkiksi jaksoja pois, tai lisätä videolle visuaalisia ja auditiivisia efektejä. Speed Run -videot muistuttavat monella tapaa Let's Play -videoita, mutta ne lasketaan yleensä omaksi lajikseen. Speed Runeissa esitetään myös videopelien pelaamista, mutta niissä päähuomio keskittyy kyseisen pelin mahdollisimman nopeaan ja tehokkaaseen läpäisyyn. Joissain tasohyppelytyylisissä peleissä voidaan etsiä pikselin tarkkuudella optimaalisia reittejä. Long Play -videot taas eroavat Let's Playstä siinä, että niissä ei ole lainkaan kerrontaa mukana. Andrew Burnin $(2006,102)$ mukaan peleihin liittyvä fanitoiminta poikkeaa muusta mediafaniudesta siinä, että toiminnassa on erotettavissa sekä pelimekaniikkaan ja pelin suorittamiseen liittyviä tuotantoja (esim. Walkthrough-videot) että pelikerrontaan liittyviä ilmaisullisia tuotantoja (esim. fanifiktio). Let's Play -videot haastavat Burnin jaottelun jossain määrin. Ne ovat kyllä lähempänä jälkimmäistä kategoriaa, mutta sisältävät runsaasti myös pelin suorittamiseen liittyviä huomioita.

Let's Play -videoissa on siis aina mukana kerrontaa. Kerronnan sisällöstä voidaan erotalla joitain keskeisiä teemoja. Tero Kerttula (2019) on jaotellut kerronnan seitsemään eri kategoriaan:

1) kuvailu: omin sanoin, mitä ruudulla näkyy ja tapahtuu, myös oman toiminnan kuvailu

2) tarina: pelin tarinan sanallistaminen, henkilöiden motiivien spekuloiminen jne.

3) audiovisuaalisuus: pelin grafiikkaan ja ääniin liittyvät asiat

4) pelimekaniikka: pelimekaniikan käsittely, usein opettavaista tai kriittistä sävyltään

5) intertekstuaalisuus: pelin yhteydet muihin mediatuotteisiin

6) reflektio: omien valintojen ja pelin herättämien tunteiden pohtiminen

7) vaihtoehtoiset tapahtumat: ruudulla näkyvälle toiminnalle oman, vaihtoehtoisen merkityksen antava kerronta (usein parodiseen sävyyn)

Osa Let's Play -videoiden tekijöistä käyttää näitä kategorioita monipuolisesti yhdistellen, toiset taas keskittyvät yhteen tai kahteen niistä. Lisäksi on sellaisia, joille Ben Croshaw'n (2011) mukaan näyttää "pelaaja-kertojan persoonallisuus olevan olennaisempaa kuin pelattava peli", tai kuten Kerttula (2019) asian muotoilee, tällaisille Let's Play -videoiden tekijöille on tärkeämpää kertoa itsestään kuin heidän pelaamastaan pelistä. Varsinkin tällaisten Let's Play -videoiden tekijöiden kohdalla siirtymä omasta elämästään kertovaksi tubettajaksi on varsin luonteva. Pelaaja-kertoja on joka tapauksessa merkittävä osa Let's Play -videoita, jotka kertovat "jännityksestä, pettymyksestä, voitosta ja tappiosta... kertovat tarinan pelaajasta ja hänen kokemuksestaan" (Kerttula 2019, 3). Game of Thrones -pelin Let's Play -videoissa on tunteista vahvasti 
mukana myös turhautuminen, kun pelin lupaama mahdollisuuus osallistua tapahtumien kulkuun osoittautuu hyvin rajalliseksi.

Yleisesti Game of Thronesin Let's Play -videoista voidaan todeta, että suuri osa niiden tekijöistä on nähnyt myös televisiosarjan, tai ainakin osan siitä. Monet heistä viittaavat pelikerronnan yhteydessä televisiosarjaan ja omiin kokemuksiinsa sitä katsoessaan. Nämä Let's Play -videot avaavat siten mielenkiintoisen ikkunan myös televisiosarjan vastaanottoon, sen lisäksi että kertovat Game of Thrones -pelin pelaamisesta. Joissain tapauksessa videoissa viitataan myös Martinin kirjasarjaan, mutta nämä viitteet ovat huomattavasti vähäisempiä. Let's Play -videoiden ohella suosittuja ovat olleet ns. reaktiovideot, joissa näytetään kuinka Valtaistuinpelin tapahtumista ennakolta tietämättömät katsojat reagoivat nähdessään jonkin erityisen dramaattisen kohtauksen ensimmäistä kertaa. Muun muassa Red Wedding -jakson julma huipennus sekä Ned Starkin mestaus ovat tuottaneet joukon reaktiovideoita, jotka ovat kiertäneet meemeinä netin eri alustoilla. ${ }^{4}$ Nämä poikkevat luonteeltaan Let's Play -videoista monin tavoin keskittyessään vain yhteen kohtaukseen ja kuvaajana sekä mahdollisesti myös kertojana toimiva henkilö on eri kuin se, jonka reaktioita esitetään. Reaktiovideot tarjoavat omalla tavallaan ikkunan populaarikulttuurin seuraajien kokemuksiin ja ne ovat voineet toimia myös mallina oman kokemuksen dramatisoinnille Let's Play -videoissa.

\section{Aineisto ja yleisiä havaintoja}

Käyttämäni aineisto on koottu lähinnä satunnaisotantana kahdelta eri videonjakoalustalta. Videoista yksi on julkaistu Twitchissä, loput yhdeksän Youtubessa. Olen ottanut mukaan vain englanninkielisiä videoita, pyrkien siihen, että mukana olisi niin mies- kuin naispuolisiakin pelaajia, sekä suuren yleisön kerääviä että vähemmän suosittuja videoita. Kaikki vaikuttavat siltä, että ne on tehty sokkona, mutta tätä ei aina pysty päättelemään, ellei pelaaja-kertoja asiaa erikseen mainitse. Peli on julkaistu kuutena episodina, ja Let's Play -videot on pääsääntöisesti julkaistu myös episodeittain. Olen tässä työssä tarkastellut ainoastaan pelin ensimmäisen episodin videointeja ja niihin liittyvää kommentointia. Mukana ovat seuraavat videot:

Moonclaw196: mies, näkyy kuvassa, tuntee tv-sarjan (20 katsomiskertaa), Twitch

Lavinia: nainen, ei näy kuvassa, pitää kirjoista, nähnyt kaksi ensimmäistä kautta sarjasta (7 500+ katsomiskertaa), Youtube

EmmaExegames: nainen, näkyy kuvassa, tuntee sarjan (8 500+ katsomiskertaa), Youtube

PewDiePie: mies, näkyy kuvassa, ei lukenut kirjoja eikä seurannut sarjaa (4,2M+ katsomiskertaa), Youtube

TheEnglishSimmer: nainen, näkyy kuvassa, nähnyt sarja, ei ole (vielä) lukenut kirjoja (19 000+ katsomiskertaa), Youtube

ChristopherOdd: mies, ei näy kuvassa, tuntee sarjan (42 000+ katsomiskertaa), YouTube

Wretch Plays: mies, ei näy kuvassa, tuntee sarjan, ei ole lukenut kirjoja (11 000+ katsomiskertaa), Youtube

SwingPoynt: mies, näkyy kuvassa, ei paljon kokemusta kirjoista tai sarjasta (53 000+ katsomiskertaa), Youtube
4 Katso esim. Game of Thrones: Red Wedding Reactions Compilation YouTubessa: <https://www.youtube.com/ watch?v=78juOpTM3tE>. Linkki tarkistettu 23.11.2019. 
Kathleenmms: nainen, näkyy kuvassa, Game of Thrones -fani (3 200+ katsomiskertaa), Youtube

WhiteBoy7thst: mies, näkyy kuvassa, tuntee sarjan (57 000+ katsomiskertaa), Youtube

Se, missä määrin pelaaja-kertoja tuntee Martinin kirjoja tai televisiosarjaa, on edellä määritelty videoissa sanotun pohjalta. Lisäksi osa pelaajista osallistuu videonsa yhteydessä käytävään keskusteluun ja voi myös siellä kertoa tarkemmin suhteestaan Valtaistuinpeli-transmediauniversumiin.

Game of Thrones -pelin pelaajista monilla on vahvoja ennakko-odotuksia pelin suhteen ja ennakko-odotukset ovat erityisesti televisiosarjan luomia. Esimerkiksi Ramsay Boltonin ilmestyessä näytölle tai Red Wedding -jakson tapahtumiin viitatessa jotkut pelaaja-kertojat ilmaisevat pelkonsa seuraavien tapahtumien suhteen, koska he tietävät Ramsayn sadistisuuden ja Red Weddingin järkyttävyyden. Monien viitteiden suhteen on vaikea tietää varmasti, onko pelaaja nähdnyt tapahtumat televisiosarjasta, vai lukenut kirjoista, mutta monet seikat puhuvat televisiosarjan puolesta. Sekä Ramsay Bolton että Red Wedding -jakson tapahtumapaikka on esitetty televisiosarjan mukaisesti, ja pelaaja voi tunnistaa ne, vaikka itse pelissä niitä ei välttämättä suoraan nimetä. Ja kuten edellä on todettu, pelaaja-kertojat monessa tapauksessa itse kertovat, että ovat esimerkiksi seuranneet sarjaa, mutta eivät lukeneet kirjoja. Joissain tapauksissa viite televisiosarjaan on selkeä, kuten silloin, kun pelaajat alkavat viheltää tai hyräillä tunnusmusiikin alkaessa soida, mikä osoittaa, että he tuntevat kyseisen televisiosarjaan sävelletyn intron entuudestaan.

Tässä otoksessa ei juurikaan ole Let's Play -tekijöitä, jotka keskittyisivät enemmän itseensä kuin pelattavaan peliin. Poikkeuksena on lähinnä ruotsalainen PewDiePie, joka on myös yksi harvoista mukana olevista, joka ei ole juurikaan tutustutunut Valtaistuinpeliin ennen pelin pelaamista. Ääniraidalla pelaaja-kertojat ensisijaisesti sanallistavat ruudulla näkyviä tapahtumia ja käyttävät runsaasti aikaa myös pelin edellyttämien moraalisten valintojen pohtimiseen ja selittämiseen. Videoissa on myös tärkeässä roolissa pelaajakertojien tunnereaktioiden esittäminen ja tämän osalta on syytä nostaa esiin Let's Play -videoiden performatiivinen luonne. Pelaaja-kertojat ovat ilmeisen tietoisia yleisöstään, jolle he esiintyvät. Heidän sanomisia ei siten pidä tulkita suoraan heidän mielipiteinään ja kokemuksinaan sellaisinaan, vaan kyseessä voi olla myös jonkinlaisen roolin esittäminen. On syytä muistaa, että "[a]lakulttuureissa tyyli on kyllästetty merkityksillä" (Hirsjärvi 2009, 65).

\section{Fanius esityksenä}

Faniuden tarkastely Let's Play -videoiden kautta sopii hyvin yhteen Matt Hillsin näkemykseen siitä, että fanius itsessään on ei-kilpailullista ja affektiivista peliä $(2002,60-64)$. Faniuteen liittyy olennaisena osana oman faniuden suorittaminen ja esittäminen. John Fiske (1992, 37-39) on erotellut faniuteen liittyvät kolme eri toiminnan tasoa:

1. Semioottinen tuottaminen: sosiaalisen identiteetin ja kokemusten rakentaminen kulttuurisen hyödykkeen semioottisten resurssien pohjalta

2. Ilmaiseva tuottaminen: edellisen tason merkitysten jakaminen kasvokkaisissa tilanteissa tai suullisen kulttuurin piirissä 
3. Tekstuaalinen tuottaminen: fanit tuottavat ja kierrättävät keskuudessaan tekstejä, jotka usein on valmistettu hyvinkin laadukkaasti

Let's Play -videot itsessään kuuluvat tason kolme tekstuaaliseen tuottamiseen, mutta ne kertovat myös ensimmäisen tason semioottisesta tuottamisesta. Videoiden kommenttikentässä käytävä keskustelu puolestaan on lähellä tason 2 ilmaisevaa tuottamista, vaikka tapahtuukin verkossa kasvokkaisen tilanteen sijaan. Videoilla niiden tekijät esittävät Valtaistuinpeli-faniuttaan pelaamisen kautta eli he tekevät faniudestaan esityksen. Tällaisissa Let's Play -videoissa olennaista ei siis ole niinkään esittää videon tekijän taitoja ja kokemusta pelaajana, vaan nimenomaan heidän fanittamistaan. Erving Goffmanin näyttämömetaforaan pohjautuvan identiteettiteorian mukaan ihminen on aina ikään kuin näyttämöllä ja näyttelee omaa rooliaan kanssaihmisille. Koko elämä ei jatkuvasti tapahdu näyttämöllä, vaan välillä on mahdollisuus vetäytyä taustaalueelle (backstage) $(1956$, 13-19; 69-70). Goffman oli itse kiinnostunut lähinnä kasvokkaisesta vuorovaikutuksesta, mutta hänen teoriaansa on sovellettu laajasti myös online-ympäristöihin (ks. esim. Pearson 2009). Let's Play -videoissa goffmanilainen näyttämö ja tausta-alue sekoittuvat, kun pelaaja-kertoja tietoisesti esittää yleisölleen tapahtumaa (yksinpelin pelaamista) eli avaa tausta-alueen kanssaihmisten nähtäväksi. Tällöin yksityisestä pelaaja-henkilöstö kuoriutuu pelaaja-kertojan roolin esittäjä. Tätä tausta-alueen avaamista korostaa se, kuinka joissain Let's Play -videoissa näkyy pelaaja-kertojan osa asuntoa, yksityistä, intiimiä tilaa. Erika Pearson kutsuu tätä ilmiötä käsitteellä accessible privacy (mt., $\mathrm{np}$ ). Sen lisäksi, että pelaaja-kertojat ottavat roolin esittämisen moodin goffmanilaisessa mielessä, mukaan tulee usein myös näyttelemisen piirteitä: pelaaja-kertoja näyttelee yleisölleen ikään kuin olisi osa pelissä tapahtuvaa draamaa. Editoimattomia, sokkona tehtyjä Let's Play -videoita ei ole voitu juurikaan suunnitella etukäteen, puhumattakaan käsikirjoittamisesta, joten näytteleminen vertautuu lähinnä improvisaatioon tai taiteelliseen performanssiin.

Esittämisen ja näyttelemisen kautta pelaaja-kertojat tuovat myös epäsuorasti esiin suhtautumistaan Valtaistuinpeliin kokonaisuudessaan sekä sen henkilöihin ja tapahtumiin, esimerkiksi valinnoillaan, minkä hahmojen rooleja he esittävät. Fiktiivisiin maailmoihin kiinnittyminen tapahtuukin usein henkilöhahmojen kautta (ks. esim. Välisalo 2017). Tässäkin aineistossa on voimakkaita kannanottoja henkilöiden suhteen ja heidän luonteenpiirteensä nousevat usein tarkastelun kohteeksi. Ihmisillä on tyypillisesti suosikki- ja inhokkihahmoja fiktiivisessä henkilögalleriassa: "Oo-oh, here's Tyrion, he is one of my favourite... He and Arya." (Lavinia), "Ramsay is one despicable person - I hate him so much!" (kathleenmms). Ramsay Boltonin yhteydessä voidaan ehkä puhua antifaniudesta eli ilmiöstä, jossa ihmiset kuluttavat niin paljon aikaa ja vaivaa inhoamansa asian seuraamiseen ja kommentointiin, että se jakaa runsaasti piirteitä positiivisen faniuden kanssa. (Ks. esim. Hirsjärvi 2009, 66.) Varsinkin näiden inhosuhteiden esittäminen saa liioittelevan voimakkaita piirteitä Let's Play -videoilla. Tällaisissa kohdissa näytteleminen Let's Play -videon yleisölle voi dominoida suhteessa goffmanilaisen taustaalan (yksityisen vastaanoton ja kokemuksen) esittämiseen.

Esittäminen ja näytteleminen sinänsä eivät ole mitenkään poikkeavaa toimintaa fanikulttuurien piirissä. Erityisesti cosplay-harrastuksessa pukujen valmistamisen ja esittelemisen ohella voidaan näytellä myös kohtauksia, joissa suosikkihahmo esiintyy. Myös filkkaaminen, tuttujen laulujen esittäminen omilla sanoituksilla on ainakin scifi-fandomissa tuttua. Cosplayssa mediateks- 
ti, josta esitettävä hahmo on peräisin, ei välttämättä ole lainkaan keskiössä, vaan olennaista on cosplay-harrastajan, mediatekstin sekä pukeutumisen muodostama kokonaisuus (Lamerichs 2015, 113). Vastaavalla tavalla Game of Thronesin Let's Play -videoissa tärkeää on pelaaja-kertojan persoonallisuuden, Valtaistuinpelin ja pelaamisen kokonaisuus, johon läheisesti liittyy myös seuraajien kommentit. Esittämisen osalta Let's Play -videoissa on merkittävää goffmanilaisen tausta-alueen ja näyttämön sekoittuminen, mitä esimerkiksi cosplayssa ei vastaavalla tavalla tapahdu.

Pelien erityispiirteenä suhteessa muihin mediamuotoihin on se, kuinka osa fiktiivisistä hahmoista on ns. pelattavia, eli pelaaja pystyy itse vaikuttamaan heidän valintoihinsa ja muihin toimiinsa fiktiivisessä maailmassa. Tämän otoksen perusteella näyttää siltä, että suhtautumisessa Valtaistuinpelin kautta tuttuihin hahmoihin ja Game of Thrones -pelin omiin hahmoihin ei ole mitään olennaista eroa sen jälkeen, kun pelaaja on ehtinyt tutustua pelin uusiin hahmoihin. Pelaaja-kertojat vaihtelevat tyyliään erityisesti roolipelaamisen ja reflektion välillä käsitellessään hahmoja, paikoitellen eläytyen hahmon asemaan, paikoitellen pohtien tämän vaihtoehtoja ja motiiveja. Elisa Wiikin (2019) transmediafaniuden tutkimuksessa nousi aivan samalla tavalla esiin kaksi tapaa suhtautua transmediasisältöihin: identifikaatio eli fiktiohahmon roolipelaaminen sekä "ensimmäisen persoonan" omakohtainen kokeminen (johon ei liity hahmoon identifioitumista).

Pelihahmoihin liittyy aineistossa kaksikin kohtausta, jotka onnistuvat yllättämään useat pelaaja-kertojista siitäkin huolimatta, että ne omalla tavallaan noudattavat kirjojen ja televisiosarjan logiikkaa. Aivan pelin alussa yhdellä pelihahmoista on isällinen rooli pelaajahahmoa kohtaan ja hänen toimintansa muistuttaa jossain määrin monissa videopeleissä käytettävää mentori-hahmoa, joka opastaa pelaajan pelimaailman toimintoihin. Kun mentori-hahmo kuolee jo ensimmäisen episodin alkuvaiheissa, tämä herättää tyrmistyneitä reaktioita pelaajissa:"He needs to be my mentor, he can't be killed like before the 3rd episode" (kathleenmms). Vielä yllättävämmäksi osoittautuu kohtaus, jossa yksi pelattavista hahmoista tapetaan. Vaikka Martinin kirjat ja televisiosarja ovat opettaneet ihmiset siihen, että myös päähenkilön asemassa olevat hahmot saattavat tässä tarinassa kuolla kesken kaiken, pelien logiikka, jonka mukaisesti pelattavat hahmot eivät kuole (tai voivat kuolla monestikin, mutta tällöin peli käynnistyy uudestaan aiemmasta kohdasta ja hahmo on jälleen hengissä) on niin paljon vahvempi, etteivät pelaaja-kertojat ole uskoa näkemäänsä:"'They really just killed the main character! I was not expecting that!" (kathleenmms)

Peleissä kuolema ei normaalisti ole samalla tavalla lopullinen kohtalo kuin elämässä tai kertovassa fiktiossa. Pelihahmon kuolema on enemmänkin yksi haaste pelimaailmassa ja lähinnä tapa osoittaa pelajan epäonnistuneen tietyssä tehtävässä. Varsinaisesta kuolemasta ei voi oikeastaan edes puhua, kun hahmo on välittömästi jälleen valmis uuteen yritykseen. Osittain tämä liittyy pelimaailmojen luonteeseen, siihen kuinka ne ovat vain osittain mimeettisyyteen pyrkiviä (pelistä ja genrestä riippuen) ja osittain pelimekaniikan keinoin toimivia systeemejä ("half-real" Jesper Juulin termein; 2005, 1), jolloin pelihahmotkin ovat osa pelimekaniikkaa. Osa peleistä on pyrkinyt rikkomaan tätä konventiota, tekemällä pelattavan ja usein työläästi kehitettävän hahmon kuolemasta pysyvän (ns. perma-death). Joka tapauksessa pelikerronta on kehittynyt kunnianhimoisemmaksi ja pelihahmot samalla entistä "kokonaisemmiksi", ja tällaisissa pelimaailmoissa hahmojen kuolemastakin tulee merkittävämpi kokemus. Game of Thrones -peli liittyy osaltaan tällaiseen kehitykseen, mutta 
siitä huolimatta ajatus pelattavan hahmon kertakaikkisesta kuolemasta on jopa tässä peligenressä edelleen pelaajille järkyttävä kokemus.

\section{Fanikulttuurinen pääoma}

Keskeinen asema faniuden esittämisessä on fanikulttuurisen pääoman ja laajemmin populaarikulttuurin tuntemuksen esittelyssä. Pierre Bourdieu (1986, 233) jakaa kulttuurisen pääoman käsitteensä kolmeen eri osa-alueeseen: sisäistettyyn, objektivoituun sekä institutionalisoituun. Faniuteen liittyy kaikkia näitä kulttuurisen pääoman muotoja, mutta nimenomaan fanikulttuurinen pääoma on institutionalisoitua. Kyseessä eivät niinkään ole viralliset instituutiot (vaikka nekin ovat mukana lisääntyvässä määrin, esimerkkinä vaikkapa pelitaiteen edustaja läänintaitelijana), vaan fanien omat arvo- ja arvostusjärjestelmät (Taalas \& Hirsjärvi 2008; ks. myös Hills 2002, 19). Faniuden kohteena olevan mediailmiön laaja-alainen asiantuntemus on merkittävä osa kulttuurista pääomaa, mutta sen ohella tärkeässä asemassa on myös tietojen, taitojen ja aineistojen vaihto sekä laajemmin symbolinen vaihdanta fandomin piirissä (Taalas \& Hirsjärvi 2008, 210-211). Let's Play -videoiden pelaaja-kertojat eivät välttämättä ole kaikkein perusteellisimmin Valtaistuinpelin maailmaan perehtyneitä faneja, mutta saavuttavat fanikulttuurista pääomaa tuottamalla muille faneille olennaista sisältöä ja lisäarvoa tähän transmediauniversumiin. Game of Thronesin Let's Play -videoissa fanius ei kuitenkaan rajoitu pelkästään Valtaistuinpeliin, vaan se kohdistuu myös fantasiagenreen laajemmin sekä muihin Telltalen peleihin.

Osa pelaaja-kertojista viittaa Game of Thrones -pelin yhteydessä muihin Telltale Gamesin tekemiin peleihin, joita he ovat aiemmin pelanneet. Eräs pelaajista kertoo, ettei tiedä juurikaan Valtaistuinpeli-sarjasta, mutta on pelannut runsaasti Telltalen pelejä. Tässä tapauksessa ennakko-odotukset siis nousevat selkeästi Telltalen pelien tyylistä eikä Valtaistuinpelin transmediauniversumista. Usein pelitalojen eri pelit jakavat tiettyjä, tunnistettavia piirteitä, joten pelaajilla on hyvä syykin odottaa uuden pelin noudattavan pelitalon aiempien pelien tyyliä. Viittaus voi myös samanaikaisesti sekä kertoa pelitalon synnyttämistä odotuksista että toimia intertektsuaalisena viitteenä, kuten pelaaja-kertojan viitatessa Walking Dead -transmediauniversumiin (lähtökohtana sarjakuva) ja erityisesti siihen liittyvään Telltalen tekemään peliin mutta myös televisiosarjaan: "I' $m$ a huge fan of Walking Dead, the tv show and the video game ... I love the games where you make choices and it effects the story mode" (WhiteBoy7thst).

Osa pelaaja-kertojista puhuu pelin yhteydessä laajemmin Tulen ja jään laulu -kirjasarjan ympärille rakentuneesta transmediaalisesta kokonaisuudesta ja heillä on ilmeinen ymmärrys pelin asemasta tässä kokonaisuudessa: "I understand the game runs concurrently to the books and tv series; is situated somewhere after the season 3" (ChristopherOdd). Myös maininnat siitä, että pelaaja on lukenut peliin sisältyvää Codexia (pelimaailman henkilöiden, tapahtumien ja paikkojen tietokirjamaisia kuvauksia) liittyy tähän kategoriaan, sillä Codex sitoo pelin hahmoja ja tapahtumia laajempaan transmediaaliseen maailmaan.

Aineistosta löytyy runsaasti intertekstuaalisia viitteitä. Telltalen peleihin on enemmänkin viitteitä kuin edellä mainittu Walking Dead. Esimerkiksi sekä Wolf among Us -ihmissusitarina (Telltale Games 2014; perustuu Bill Willinghamin sarjakuvaan Fables, DC Comics Vertigo, 2002-2015) että scifi-peli Tales from the 
Borderlands (Telltale Games 2014; perustuu Gearboxin Borderlands-pelisarjaan, ensimmäinen peli 2009) mainitaan kerronnassa. Yksi pelaaja-kertojista huomauttaa Forresterien vaakunan muistuttavan Gondorin puuvaakunaa Taru Sormusten Herrasta -elokuvissa. Yksi pelin hahmoista taas saa pelaajalta lempinimen "Wolverine-tyyppi", viittauksena Marvelin supersankariin ja ilmeisesti nimenomaan Wolverine-elokuvaan (2013): "Wolverine guy saved my back!" (WhiteBoy7thst). Lennokkaampaan ideointiin innostui pelaaja, joka kertoi pitävänsä erityisesti zombitarinoista, vaikka Game of Thrones on lähes yhtä hyvä, mutta toivoi uutta aluevaltausta televisiosarjojen pelillistämisessä: " A Breaking Bad game would be cool!" (WhiteBoy7thst). Populaarikulttuurin vastaanotto on tyypillisesti hyvin intertekstuaalista, varsinkin tietyn genren sisällä tai lähigenrejen väillä. Joissain tapauksissa on vaikea sanoa, puhuuko pelaaja-kertoja tietyn populaarikulttuurin genren konventioista, vai yleisemmistä ("arkkityyppisistä") tarinarakenteista, kuten silloin, kun hän toteaa seikkailijan perheen aina kuolevan harharetkien aikana: "I don't know why the family always has to die when they go for adventure." (PewDiePie)

\section{Vahvistava ja vastustava fanitoiminta}

Fanitoiminnan kaksi päämoodia ovat vahvistava (affirmative) ja vastustava (resistant), joista ensimmäinen hyväksyy tietyn tarinamaailman sellaisena kuin se on julkaistu ja vahvistaa tämän tarinamaailman kanonisia piirteitä. Vastustava fanitoiminta taas pyrkii luomaan kanonisesta tarinamaailmasta poikkevia esityksiä, jotka paremmin vastaavat fanin omia toiveita.

Vahvistava toiminta voi näkyä hyvinkin pienissä yksityiskohdissa. Eräässä kohtauksessa pelaajan tulee valita, mitä pelihahmo sanoo, ja yksi vaihtoehdoista on "Winter is coming". Kun eräs pelaajista valitsee tämän vaihtoehdon, hän kommentoi ääniraidalla, "Somebody's gotta say it, it's the series slogan!"(ChristopherOdd). Monet pelaaja-kertojista taas alkavat hyräillä tai viheltää tunnusmusiikin alkaessa soida ja ilmaisevat tyytyväisyytensä siihen, että tv-sarjan tunnusmusiikki on mukana myös pelissä: "This is probably the best intro in television history". Fanit ovat omaksuneet Valtaistuinpelin elementtejä osaksi omaa ilmaisullista repertuaariaan. Tällainen uskollisuus ja toisto kuuluvat osaksi faniutta yleisemminkin (Hirsjärvi \& Kovala 2007, 208).

Väkivallan ja raakojen kohtausten osalta taas mainitaan usein, että ne kuuluvat Valtaistuinpelin maailmaan, ja niiden mukanaoloa pelissä pidetään sen aitoutta lisäävänä tekijänä. Peli saa arvostusta siitä, että se noudattaa Valtaistuinpelin transmediauniversumin piirrettä, jota fanit ilmeisesti suuresti arvostavat.

Vastustavan fanitoiminnan suhteen aineistosta löytyy joitain esimerkkejä. Ehkä merkittävin ero Game of Thrones -pelin ja Valtaistuinpeli-televisiosarjan välillä on seksin ja alastomuuden täydellinen puuttuminen pelistä. Pelaajakertojat eivät kuitenkaan juurikaan kiinnitä tähän eroon huomiota. Aineistossa on yksi poikkeushenkilö, joka tuo heti alusta lähtien selväksi, että odottaa peliltä rohkeaa seksuaalista sisältöä eikä peittele pettymystään, kun sitä ei olekaan tarjolla. Kun lordi Forrester kysyy pelihahmolta, mitä tämä toivoisi palkkiokseen, pelaaja-kertoja vastaa ääniraidalla: "Can you give me a bunch of prostitutes? Why wasn't prostitutes an option, goddamit!?" (kathleenmms). Myöskään videoiden kommenttiosioissa ei juuri puututa seksuaaliseen sisältöön tai sen puutteeseen, vaikka eräs kommentoija kuvaakin kuningatar Margaery olleen "seksikäs". Martinin kirjoissa seksiä käsitellään suorasukai- 
sesti, mutta yleensä melko lyhyesti ja ilman yksityiskohtiin paneutumista. Televisiosarjassa, ja varsinkin alkukausien jaksoissa, alastomuus on paikoitellen tarkoitushakuisen oloista ja prime time -sarjaksi hyvinkin rohkeaa. Kun pelaaja-kertojille televisiosarja on selkeästi tärkeämpi lähtökohta kuin kirjat, on jossain määrin yllättävää, että näinkin näkyvän osuuden puuttuminen peleistä ei herätä enempää reaktioita.

\section{Let's Play -pelaajat fanituksen kohteena}

Aineistona olevien Let's Play -videoiden kommenttiosiossa käytävä keskustelu sisältää runsaasti osoituksia siitä, kuinka videoita julkaiseviin pelaajiin itseensä suhtaudutaan fanituksen kohteina. Kun heillä parhaimmillaan on kymmeniä tuhansia seuraajia (ja PewDiePien tapauksessa kymmeniä miljoonia), voidaan heitä hyvinkin pitää vähintään mikrojulkkiksina. On kuitenkin hyvä pitää mielessä Tullochin \& Jenkinsin $(1995,23)$ jaottelu fanien ja seuraajien välillä. Suosittujen Let's Play -pelaajien yleisö ei automaattisesti ole kaikki faneja, vaan suurin osa heistä on tavallisia seuraajia ja pienempi osa sitoutunut faniuden edellyttämällä tavalla. Aineistossa olevat Let's Play -videoiden tekijät eivät omassa tuotannossaan keskity pelkästään Game of Thrones -peliin tai Valtaistuinpelin transmediaaliseen kokonaisuuteen, vaan pelaavat monia muitakin pelejä. Fani-seuraajat eivät siis välttämättä fanita heitä nimenomaan ja pelkästään Game of Thronesin Let's Play -videoiden vuoksi, mutta aineistosta löytyy suoria viittauksia siihen, että kyseiset Game of Thrones -videot ovat lisänneet pelaaja-kertojien fanikulttuurista pääomaa Valtaistuinpelin fanien keskuudessa.

Keskusteluaineiston pohjalta on ilmeistä, että pelaaja-kertojien tunnereaktiot, niiden aitoudesta ja tyypillisestä liioittelusta riippumatta, näyttävät olevan tärkeä syy videoiden katseluun: "Haha, I loved your reaction, I think for this one I'll dump all the famous youtubers and watch the second episode on your channel : $\mathrm{D}^{\prime \prime}$ (Lavinia, kommenttiosasto). Steve Dixon on kirjoittanut siitä, kuinka online-viestintään liittyy lähtökohtaisesti esittäminen ja hahmon luominen: "Personas are honed like characters for the new theatrical confessional box, where, like postmodern performance artists, individuals explore their autobiographies and enact intimate dialogues with their inner selves" $(2007,4)$. Vaikka tämä yleistyksenä tuntuu liian voimakkaalta, se pätee erittäin hyvin Game of Thronesin Let's Play -videoihin, joissa tällaista intiimiteatteria esitetään ihailevalle yleisölle.

Myös moraalinen pohdinta näyttää kiinnostavan videoiden katsojia: "I really admire your intelligent commentary on the ethical considerations of the games you play" (Lavinia, kommenttiosasto). Voidaan olettaa, että Game of Thrones -pelin luonne johtaa keskustelun nimenomaan moraalisten pohdintojen suuntaan, eivätkä ne ole välttämättä samalla tavalla esillä muun tyyppisten pelien Let's Play -videoissa. Kuten edellinen sitaatti osoittaa, moraalisia valintoja peleissä kohdatessaan monet pelaajat ovat halukkaita perustelemaan valintojaan, silloinkin kun kyse on yksinpelistä eivätkä valinnat vaikuta muihin ihmisiin millään tavalla.

Pelaaja-kertojat osallistuvat keskusteluun katsojiensa kanssa ja pohtivat yhdessä ratkaisujaan: "Some choices were very difficult to make, and I'd like to know what you guys think?" (ChristopherOdd). Tällainen yhteyden hakeminen seuraajien kanssa vahvistaa faniuden yhteisöllisyyttä ja on myös esimerkki faniuden piirissä syntyvistä uusista yhteisöllisyyden muodoista (kts. Hirsjärvi \& Kovala 2007, 208). Let's Play -videoiden tekijät ovat samanaikaisesti 
sekä osa Valtaistuinpelin laajaa fandomia että itse fanituksen kohteita, jotka haluavat tunnustaa seuraajiensa ja faniensa merkityksen omassa toiminnassaa.

\section{Pelietiikka}

Game of Thronesin Let's Play -videoissa korostuu pelaajien moraaliset valinnat. Suuret valinnat elämästä ja kuolemasta tarjoavat näyttäviä tilaisuuksia pelaajakertojille esittää omia reaktioitaan ja vahvoja roolisuorituksia pelihahmojen nahoissa. Näissä kohdissa toisaalta paikoitellen esiintyminen murentuu ja omia pohdintoja käydään läpi varsin aidon tuntisesti. Tästä syystä käyn vielä tarkemmin läpi pelaamisen etiikkaan liittyviä kysymyksiä. Kuten edellä on todettu, läheskään kaikki pelit eivät varmasti herätä vastaavassa määrin moraalista pohdintaa, mutta Miguel Sicartin mukaan monet tietokonepelit ovat lähtökohtaisesti "eettisiä objekteja" ja niiden pelaajat "eettisiä toimijoita" (Sicart 2009). Sicartin mukaan eettisissä peleissä pelin sääntöihin ja sen mahdollistamiin pelitapoihin on upotettuna eettisiä arvoja. Simkins ja Steinkuehler (2008) ovat määritelleet tekijöitä, jotka synnyttävät eettisiä pohdintaa peleissä. Näihin kuuluu kokemus siitä, että ihminen voi vaikuttaa pelimaailmaan ja että hän voi tehdä merkityksellisiä päätöksiä. Game of Thrones -pelissä pelaajalla on mahdollisuus hänelle tarjottavien valintojen kautta vaikuttaa pelimaailmaan. Pelaajan päätösten merkityksellisyyskin todetaan pelissä (joidenkin valintojen jälkeen kuvaruudun yläkulmaan ilmestyy teksti: "[Henkilö X] muistaa tämän valintasi"). Monessa kohdassa pelaajalla ei kuitenkaan ole mahdollisuutta todentaa päätöksensä merkitystä eli hän ei voi tietää miten asiat olisivat menneet, jos hän olisi tehnyt toisenlaisen päätöksen ja olisiko tapahtumien kulku todella muuttunut. Useampi pelikerta, joilla pelaaja systemaattisesti tekee erilaisia valintoja, toki tuo valintojen seuraukset näkyviksi, tai muiden pelaajien Let's Play -videoiden seuraaminen.

Edelleen Simkinsin ja Steinkuehlerin tutkimuksen mukaan eettistä pohdintaa tukee myös peilaaminen (mirroring, tunneside pelimaailmaan ja sen henkilöihin) sekä rikas sosiaalinen konteksti. Game of Thrones -pelissä, samoin kuin koko Valtaistuinpelin transmediaalisessa universumissa, emotionaalinen side näyttää olevan hyvinkin vahva. Vaikka tässä fktiivisessä maailmassa hyvä ja paha eivät ole useinkaan selkeästi erotettavissa - hyvä esimerkki tästä on Jaime Lannister, valapatto kuninkaantappaja ja sisarensa kanssa sukurutsaisessa suhteessa useita lapsia tehnyt moraaliton seikkailija, joka toisaalta on monessa tilanteessa hyvinkin kunniallinen ja vastustajiaan arvostava taistelija - taistelevat osapuolet ovat selkeästi toisistaan erotettavissa ja yhden kannattaminen johtaa automaattisesti vahvasti polarisoituneeseen inhosuhteeseen muihin nähden. Lisäksi mukana on muutamia hyvin yksioikoisesti pahoja hahmoja (kuningas Joffrey, Ramsay Bolton), joita kohtaan kaikki keinot ovat sallittuja, koska hekään eivät kunnioita mitään moraalia.

Valtaistuinpelin transmediauniversumi ja siihen liittyvä fanien keskustelu ja heidän tuottamansa sisältö kokonaisuudessaan tarjoavat erittäin rikkaan sosiaalisen ympäristö, joka on verrattavissa MMORPG-genren roolipelien, kuten World of Warcraftin (2004, Blizzard Entertainment), ympäristöön. Let's play -videoihin liittyvä keskustelu pelaaja-kertojien ja heidän seuraajiensa välillä kertoo tämän sosiaalisen ympäristön suuresta merkityksestä vastaanotossa. Simkinsin ja Steinkuehlerin ehdot eettisistä valinnoista puhumiselle näyttäisivät siis täyttyvän Game of Thrones -pelissä. Sicartin edellyttämä eettisten arvojen mukanaolo pelirakenteen tasolla toteutuu myös, kun monet 
pelaajan valinnoista ovat nimenomaan eettisiä (valehdella vai puhua totta, osoittaa armoa vai olla armoton, jne.).

Pelaajien moraaliset valinnat ja niiden perustelut voidaan jakaa neljään ryhmään:

Arkimoraali: toiminta tavalla, joka noudattaa arkielämässä opittuja tapoja. Eräs pelaajista pohtii pitkään yhtä valintaa ja selittää samalla, kuinka Valtaistuinpelin maailmassa vain voiman käytöllä pärjää ja näyttää valmistelevan vastaavaa ratkaisua. Ratkaisun hetkellä hän kuitenkin valitsee sovittelevamman vaihtoehdon ja toteaa diplomatian olevan paras toimintatapa. Yritys toimia pelin maailmassa sen ehdoilla väistyy viime hetkellä tutumpaan neuvottelevaan lähestymistapaan.

Pelilogiikka: valinnat tehdään sen mukaan, minkä oletetaan parhaiten edistävän pelissä menestymistä. Periaatteessa valinnoilla ei tällöin ole juurikaan eettistä taustaa, mutta kun eettiset arvostukset sisältyvät pelitilanteisiin, kuten Game of Thrones -pelissä, valintoja joudutaan joka tapauksessa pohtimaan etiikan viitekehyksessä.

Fiktionaalisen maailman moraali: Tiettyä fiktionaalista maailmaa pidempään seuraamalla ihminen oppii sen sisäisen moraalikoodiston. Pelaaja voi pyrkiä toimimaan, kuten kyseissä maailmassa henkilöt yleensä toimivat. Tehtyään "kiltin" ratkaisun eräs pelaaja-kertoja katuu sitä välittömästi, koska huomaa, että Valtaistuinpelin maailmassa ei kiltteydellä pärjää: "That was really a bad move. I usually always default be nice in this games, but I forget this a $\mathrm{f}^{* * *}$ ing Game of Thrones, if you are nice..." (EmmaExegames).

Roolipeliasenne: Tällaista asennetta voi soveltaa silloinkin, kun kyseessä ei ole varsinainen roolipeli. Pelaaja eläytyy tilanteeseen kuin olisi itse fiktiivisen maailman asukas ja pohtii, kuinka tällöin toimisi niissä tilanteissa, joihin peli hänet asettaa. Yksi pelaaja-kertojista tiivistää tämän asennoitumisen kommentissaan: "I like roleplaying games, I try to do what I would do in that occasion." (ChristopherOdd).

Aineisto osoittaa selkeästi, kuinka pelaajat vaihtelevat hyvinkin joustavasti näiden moraalisten viitekehysten välillä, hyvin samantyyppisesti kuin Mia Consalvon ja kumppaneiden tutkimuksessa (Consalvo \& al. 2019, 232). Aina he eivät tunnu edes olevan itse tietoisia näistä siirtymistä. Vaikka pelaajalla olisi aikaa pohtia valintaansa ja hän tuntuisi rakentavan perusteluja tietyn viitekehyksen sisällä, hän saattaa varsinaisen valinnan hetkellä toimia aivan toisin. Let's Play -videoiden käytössä tutkimusaineistona on samanlaisia piirteitä kuin Think aloud -metodin käytössä (Ericsson \& Simon 1993). Pelaaja-kertojat kommentoivat pelaamistaan reaaliaikaisesti ja melko spontaanisti. Suurin ero on siinä, että videoiden tekijöillä on (ainakin potentiaalisesti) yleisöä, ja heidän kerronnassaan on usein performanssin piirteitä, joita Think aloud -metodi ei yleensä tuota. Tutkija voi parhaimmillaan seurata pelaaja-kertojan pohdintaa sen edistyessä ja siirtyessä viitekehyksestä toiseen: "Hey, it's Game of Thrones, it's a cruel world... I can do whatever I want [...] I honestly didn't think he would get killed" (kathleenmms). Tässä pelaaja ensin toimii fiktiivisen maailman viitekehyksessä ja valitsee siinä armottoman vaihtoehdon, joka johtaa pelattavan hahmon ystävän kuolemaan. Ensin pelaaja suhtautuu kuolemaan kevyesti asiana, joka kuuluu Valtaistuinpelin maailmaan. Hetken kuluttua, toiminnan hiukan rauhoituttua, hän kuitenkin vaikuttaa siirtyvän pikemmin 
arkimoraalin maailmaan ja hiukan selittelevään sävyyn toteaa, ettei osannut odottaa ystävän kuolevan.

Ihmisillä näyttää myös olevan vahva taipumus toimia moraalisesti hyväksyttävällä tavalla myös pelimaailmassa. Tai toisin sanoen, heillä on korkea kynnys toimia moraalittomasti, vaikka kohteena olisivat fiktiiviset hahmot ja vaikka sillä tavoin olisi mahdollista saavuttaa etua pelimaailmassa. Tässä suhteessa aineisto on täysin samassa linjassa Consalvon ja kumppaneiden $(2019,232)$ tutkimuksen kanssa. Arkipäivän moraalinen viitekehys tuntuu siis dominoivan pelilogiikan kustannuksella, tai kuten edellä mainitussa artikkelissa todetaan, pelaamisen taikakehä ei luokaan turvallista tilaa, jossa kokeilla myös moraalisesti epäilyttäviä ratkaisuja (mts.). Tämän ainakin osa pelaajista itsekin tiedostaa. Kun eräs pelaajista joutuu valitsemaan vihollishahmon tappamisen tai hengen säästämisen välillä, hän osoittaa armoa, mutta toteaa heti perään, että päätös tuskin oli järkevä pelin kannalta: "Well, he'll probably come and kill me later..." (kathleenmms).

Kyrkin, Itkosen ja Smedin tutkimus (2017) osoitti, että pelaajien moraalisen profiilin ja heidän pelivalintojensa välillä on yhteys. He havaitsivat myös ristiriitaisuuden siinä, kuinka moraalisesti motivoituneet pelaajat olivat muita valmiimpia moraalittomiin tekoihin silloin, kun teot vahingoittivat ei-pelattavia hahmoja, jotka myös olivat toimineet moraalittomasti. Vastaavan havainnon on tehnyt myös Sari Piittinen (2018) Fallout 3 -pelin kohdalla. Kyrki \& al. katsovat, että moraalisesti motivoituneet pelaajat arvioivat muita useammin muita hahmoja heidän moraalisuutensa perusteella. Game of Thronesin Let's Play -videoaineistossa on paljon tätä havaintoa tukevaa materiaalia. Eräs pelaaja-kertoja esimerkiksi alkaa nauraa, kun yksi pelihahmoista tapetaan hänen valintojensa seurauksena, ja toteaa: "I don't care, he was a dick" (kathleenmms). Hahmo siis ansaitsi kuoleman ikävän luonteensa vuoksi.

Fisken fanituotannon kolmen tason jaottelu auttaa osaltaan ymmärtämään moraalisten pohdinnan joustavaa venymistä ja ristiriitaisuuttakin Let's Play -videoissa. Sokkona pelattavassa pelissä pelaaja-kertoja kohtaa moraaliset valinnat ensimmäistä kertaa ja joutuu tekemään semioottista työtä ymmärtääkseen valintojensa reunaehdot. Samalla hän selittää valintojaan verkkoyleisölleen, joka ei Let's Play -videoiden tekovaiheessa ole reaaliaikaisesti mukana (ilmaiseva tuottaminen), ja esiintyy videotuotannossa (tekstuaalinen tuottaminen), jonka pitäisi sekä vastata kanavan tilaajien odotuksiin että houkutella sille uusia katsojia. Valintojen epäkoherenttius on tällöin osittain seurausta erilaisten viitekehysten sekoittumisesta, mikä ei kuitenkaan poista sitä, että pelaaja-kertojien eettiset kannat voivat olla aidostikin vaihtelevia ja sisäisesti ristiriitaisia.

\section{Päätelmiä}

Tämän Game of Thrones -aiheisen Let's Play -aineiston analysointi antaa vahvaa tukea hypoteesille siitä, että Let's Play -videot tarjoavat hedelmällisen aineiston populaarikulttuurin synnyttämien kokemusten tarkasteluun. Erityisesti väkivaltaiset ja moraalisesti haastavat kohtaukset kirvoittavat reaktiota ja pohdintaa tavalla, joka avaa näkymän pelaaja-kertojien yksityisyyteen ja hetkiin, jolloin hän vastaa muodostaa omaa kantaansa. Goffmanin termein videoidun pelaamisen aikana tausta-alue avautuu näyttämöksi. Toisaalta tutkimuksen kannalta aineiston suurin haaste on siinä, kuinka pelaaja-kertojat esittävät ja näyttelevät yleisölleen. Tällöin on vaikea arvioda, missä määrin 
heidän sanomisiaan tai pelisuoritustaan voi pitää aitoina ilmauksina heidän mielipiteistään tai pelitavoistaan. Esiintyessään ja fiktiivistä roolia näytellessäänkin pelaaja-kertojat paljastavat epäsuorasti omia mieltymyksiään ja mitä he odottavat yleisönsä haluavan. Tässä suhteessa aineisto kertoo myös olennaisia asioita populaarikulttuurin vastaanotosta. Videoiden yhteydessä oleva keskusteluosio on luonteeltaan toisenlainen, eivätkä tekijätkään siellä esiinny niin vahvasti, vaan kommentoivat enemmän omana itsenään.

On myös ilmeistä, että Let's Play -videoissa kuvatuilla pelilajeilla on suuri vaikutus Let's Play -videoiden esittämistapaan. Game of Thrones -peli on tarinavetoinen ja se keskittyy pelaajan moraalisiin valintoihin. Vaikka siinä on toimintajaksoja ja valinnoilla aikarajoitus, suurin osa pelistä etenee pelaajan valitsemassa tahdissa ja pelaajalla on mahdollisuus pysähtyä tarkastelemaan pelimaailmaa tai muuten vain pitää taukoja. Olennaista on myös se, että peli liittyy transmediaaliseen kokonaisuuteen, jolloin suuri osa pelaajista tuntee pelimaailman ja osan sen henkilöistä entuudestaan. Nämä ovat kaikki piirteitä, jotka tukevat ja kannustavat esiintymään joko pelihahmona tai asiantuntevana Valtaistuinpeli-fanina.

Let's Play -videot tarjoavat tavan sekä esittää että kasvattaa fanikulttuurista pääomaa. Pelaaja-kertojat tuovat esiin asiantuntemuksensa niin Valtaistuinpelin transmediaalisesta universumista kuin laajemmin populaarikulttuurin ilmiöistä. Let's Play -videoiden kautta he osallistuvat fandomin aineettomaan vaihdantaan, tuoden oman panoksensa Valtaistuinpelin universumiin - panoksen, jota heidän seuraajan näyttävät arvostavan. Arvostus on niin suurta, että osasta Let's Play -videoiden tekijöitä on itsestään tullut fanituksen kohteita.

Aineiston muodostavien videoiden pohjalta suhtautuminen viralliseen Valtaistuinpelin universumiin on pääosin myönteistä ja sitä vahvistavaa. Tvsarjaa erityisesti kehutaan monesti kaikkien aikojen parhaaksi, mutta myös pelistä pidetään: "I feel so shitty about everything I just did! - That was a great first episode, I wanna play more!" (SwingPoynt). Selkein vastustava ääni on yhdellä pelaaja-kertojalla, joka pyrki tuomaan Game of Thrones -peliin seksiä, ja osoittaa avoimesti pettymyksensä, kun peli ei tarjonnut odotuksille vastinetta.

Fandom-tutkimuksessa on ollut korostuneesti esillä se, kuinka fanitoiminnassa esitetään seksuaalisen suuntautumisen, etnisyyden ja poliittisen osallistumisen kaltaisia asioita (ks. esim. De Kloet \& van Zoonen 2007, 330). Myös laajassa kansainvälisessä The World Hobbit Projectissa, joka tarkasteli fantasian merkitystä ihmisten arjessa, havaittiin J. R. R. Tolkienin fantasiamaailman faniuteen liittyvän käsityksiä mm. sosiaalisen todellisuuden luonteesta (Barker \& Mathijs 2016, 172). Tässä aineistossa nämä yhteiskunnalliset kytkökset eivät juuri näkyneet. Pääosassa on uppoutuminen fiktiiviseen maailmaan. Tämä on tyypillistä laajempaan mediakokonaisuuteen liittyvien pelien yhteydessä, joissa fanit pääsevät osallisiksi suosikkiohjelmiensa tapahtumiin:"fans can engage with the textual structures and moments of their favoured cult shows, reactivating these in cultural practices of play" (Lancaster 2001). Pelaaminen tarjoaa mahdollisuuden tarkastella fiktion ja todellisuuden välistä raja-aluetta ja Game of Thronesin Let's Play -videot paljastavat juuri sellaista fiktiivisen pelimaailman ja arkitodellisuuden limittynyttä pohdintaa, mistä Silverstone on kirjoittanut:

Play enables the exploration of that tissue boundary between fantasy and reality. $[\ldots]$

In play we have a license to explore, both our selves and our society.

(Silverstone 1999, 64.) 
Game of Thrones -pelin Let's Play -videoissa pohdinta keskittyi moraalisiin valintoihin. Videoiden avaama näkymä pelaaja-kertojien yksityiseen vastaanottoprosessiin ja sen aikana tapahtuneeseen semioottiseen tuottamiseen näytti neljän eri moraalikoodiston dynaamisen limittymisen. Arkimoraali, fiktionaalisen maailman moraali, pelilogiikka (moraaliset valinnat pelimekaniikkana) sekä roolipeliasenne vaihtelivat pelaajittain, mutta myös saman pelaaja-kertojan kohdalla tavoilla, jotka paikoitellen yllättivät pelaajan itsensäkin. Aineisto myös vahvisti käsitystä siitä, että pelaajien on huomattavan vaikea omaksua moraalittoman "pahiksen" roolia. Tämäkin tukee ajatusta siitä, että pelaamisen taikakehä ei ole kovin tiivis ja toimi "moraalisena palomuurina", vaan pelimaailma on monin sitein yhteydessä arkitodellisuuteen. Let's Play -videot näyttävät tarjoavan faniuden esittämiselle uudenlaisen alustan, jossa intiimi, tausta-alueen vastaanoton hetki voidaan tuottaa yhteisölliseksi kokemukseksi.

Kirjoittaja toimii Suomen Akatemian rahoittamassa Pelikulttuurien tutkimuksen huippuyksikössä (21000040661).

\section{Primääriaineisto ${ }^{5}$}

MoonClaw196:"game of thrones episode 1". Saatavilla: <https://www.twitch.tv/moonclaw196/ video/118432133>

Lavinia: “House Forrester -Ep 01 Let's Play: Game of Thrones". Saatavilla: <https://www. youtube.com/watch?v=1VdnTi6-5PA>

Emmaexegames:"Let's Play: Game of Thrones", pelin ensimmäinen episodi jaettu seitsemään erilliseen videoon, kokoava soittolista. Saatavilla: $<$ https://www.youtube.com/playlist?list=P LPpaOjIgjgTzyCO7AUwHTO16QIg9IRoJA>

PewDiePie:"GAME OF THRANS - Episode 1". Saatavilla: <https://www.youtube.com/ watch?v=BI7zlb7nUUw $>$

EnglishSimmer:"Let's Play: Game of Thrones", pelin ensimmäinen episodi jaettu viiteen erilliseen videoon, kokoava soittolista. Saatavilla: <https://www.youtube.com/playlist?list=PLQ1 aCe8z6J91Nqzt4Cr9EPUCghMkrX19I>

ChristopherOdd:"Mr. Odd Plays Game of Thrones [Telltale]", pelin ensimmäinen eopisodi jaettu kuuteen erilliseen videoon, kokoava soittolista. Saatavilla: $<$ https://www.youtube.com/ playlist?list=PLj_Goi54wf0c29gm-MFIdS3CXkxSJoKxc>

Wretch Plays:"Game Of Thrones: A Telltale GamelLet's Play", pelin ensimmäinen episodi jaettu kuuteen erilliseen videoon, kokoava soittolista. Saatavilla: <https://www.youtube.com/ playlist?list=PLV0o1nXCAcPSR4eG3f40OfHRBhJ3W6YE_>

SwingPoynt:"Game of Thrones Game Let's Play", pelin ensimmäinen episodi jaettu viiteen erilliseen videoon, kokoava soittolista. Saatavilla: <https://www.youtube.com/playlist?list=P Lfq8ylsSgyWdX4r4K1xSX-TR5YYXxp3U7>

Kathleenmms:"Game of Thrones Kathleenmms Let's Play", pelin ensimmäinen episodi jaettu kuuteen erilliseen videoon, kokoava soittolista. Saatavilla: $<$ https://www.youtube.com/playli st?list=PLZo0yUl0MABjsni5EhfLoiDjY4ksnH95c>

WhiteBoy7thst:" Game of Thrones: Episode 1 - “Iron from Ice” Full Lets Play (Game of Thrones Game)". Saatavilla: <https://www.youtube.com/watch?v=0tm0KYN5GY8>
5 Kaikki linkit tarkastettu 23.11.2019. 


\section{Lähteet}

Anon. (arvioitavana) Constructing a Transmedia Universe: The Case of Battlestar Galactica. Barker, Martin \& Mathijs, Ernest (2017) Introduction: The World Hobbit Project. Participations $13: 2,158-174$.

Bourdieu, Pierre (1986) The forms of capital. Teoksessa John G. Richardson (toim.) Handbook of Theory and Research for the Sociology of Education. Westport, CT: Greenwood, 241-58.

Burn, Andrew (2006) Reworking the Text: Online Fandom. Teoksessa Diane Carr (toim.) Computer Games: Text, Narrative and Play. Cambridge: Polity Press, 88-102.

Consalvo, Mia \& Busch, Thorsten \& Jong, Carolyn (2019) Playing a Better Me: How Players RehearseTheir Ethos viaMoral Choices. Games and Culture 14:3, 216-235.

Cronshaw, Ben (2011) Let's Talk About Let's Play. The Escapist 8.3.2011. Saatavilla: <https:// v1.escapistmagazine.com/articles/view/video-games/columns/extra-punctuation/8703-Let-sTalk-About-Let-s-Play.2>

De Kloet, Jeroen \& van Zoonen, Liesbet (2007) Fan Culture - Performing Difference. Teoksessa Eoin Devereux (toim.) Media studies: Key issues and debates. London, UK: Sage, 322-341.

Dixon, Steve (2007) Digital Performance. A History of New Media in Theater, Dance, Performance Art, and Installation. Cambridge, MA: The MIT Press.

Fiske, John (1992) The Cultural Economy of Fandom. Teoksessa Lisa A. Lewis (toim.) The Adoring Audience. Fan Culture and Popular Media. London: Routledge, 30-49.

Goffman, Erving (1956) The Presentation of Self in Everyday Life. Social Sciences Research Centre Monograph No. 2. Edinburgh: The University of Edinburgh.

Hills, Matt (2002) Fan Cultures. London \& New York: Routledge.

Hirsjärvi, Irma (2009) Faniuden siirtymiä. Suomalaisen science fiction -fandomin verkostot. Nykykulttuuri 98. Jyväskylä: Jyväskylän yliopisto.

Hirsjärvi, Irma \& Kovala, Urpo (2007) Fanius kulttuurintutkimuksen kohteena. Teoksessa Erkki Vainikkala \& Henna Mikkola (toim.) Nykyaika kulttuurintutkimuksessa. Nykykulttuurin tutkimuskeskuksen julkaisuja 86. Jyväskylä: Jyväskylän yliopisto, 245-269.

Juul, Jesper (2005) Half-Real. Video Games between Real Rules and Fictional Worlds. Cambridge, MA: The MIT Press.

Kerttula, Tero (2019) "What an Eccentric Performance": Storytelling in Online Let's Plays. Games and Culture 14:3, 236-255.

Kyrki, Juhani \& Itkonen, Eero \& Smed, Jouni (2017) Studying Interactive Storytelling System Regicide: Part II. Morality, Computers in Entertainment. Saatavilla: <https://cie.acm.org/articles/ studying-interactive-storytelling-system-regicide-part-ii-morality/>

Lamerichs, Nicolle (2015) Express Yourself: An Affective Analysis of Game Cosplayers. Teoksessa Jessica Enevold \& Esther MacCallum-Stewart (toim.) Game Love. Essays on Play and Affection. Jefferson, North Carolina: McFarland, 97-115.

Lancaster, Kurt (2001) Interacting with 'Babylon 5': Fan Performances in a Media Universe. Austin: University of Texas Press.

Mittell, Jason (2015) Complex TV. The Poetics of Contemporary Television Storytelling. New York and London: New York University Press.

Pearson, Erika (2009) All the World Wide Web's a stage: The performance of identity in online social networks. First Monday 14:3. Saatavilla: <https://firstmonday.org/ojs/index.php/fm/ article/view/2162/2127>

Piittinen, Sari (2018) Reconstructing the Gothic in games and gaming: Gothic monsters and ideology in the story world and player experiences of Fallout 3. Jyväskylä: Jyväskylän yliopisto.

Scolari, Carlos (2009) Transmedia Storytelling: Implicit Consumers, Narrative Worlds, and Branding in Contemporary Media Production. International Journal of Communication 3, 586-606.

Sicart, Miguel (2009) The Ethics of Computer Games. Cambridge, MA: The MIT Press.

Silverstone, Roger (1999) Why Study the Media? London: Sage.

Simkins, David W. \& Steinkuehler, Constance (2008) Critical Ethical Reasoning and Role-Play. Games and Culture 3:3-4, 333-355. 
Simon, Herbert A. \& Ericsson, K. Anders (1993) Protocol Analysis: Verbal Reports as Data. Cambridge, MA: The MIT Press.

Taalas, Saara \& Hirsjärvi, Irma (2008) Fanit ja seuraajat. Tieteiskirjallisuuden kuluttamisen organisoituminen. Teoksessa Kaarina Nikunen (toim.) Fanikirja. Tutkimuksia nykykulttuurin fani-ilmiöistä. Nykykulttuuri 96. Jyväskylä: Jyväskylän yliopisto.

Tulloch, John \& Jenkins, Henry (1995) Science Fiction Audiences: Watching Star Trek and Doctor Who. New York: NY: Routledge.

Välisalo, Tanja (2017) Engaging with film characters: Empirical study on the reception of characters in The Hobbit films. Fafnir: Nordic Journal of Science Fiction and Fantasy Research 4:3-4, 12-30.

Wiik, Elisa (2019) “More Interaction, More Story, More Lore”: Motivations Related to Gamecentric Transmedia. Teoksessa DiGRA '19 - Proceedings of the 2019 DiGRA International Conference: Game, Play and the Emerging Ludo-Mix. <http://www.digra.org/wp-content/uploads/ digital-library/DiGRA_2019_paper_321.pdf> 